\title{
TOWARDS OVERCOMING THE CONFLICT BETWEEN ENVIRONMENTAL TAX LEAKAGE AND BORDER TAX ADJUSTMENT CONCESSIONS FOR DEVELOPING COUNTRIES
}

Jon M. Truby ${ }^{*}$

\section{TABLE OF CONTENTS}

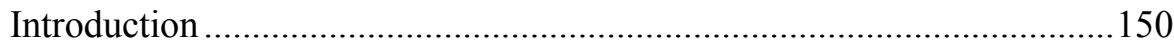

I. Background: Unilateral Environmental Objectives ................................151

II. Border Tax Adjustments...................................................................153

III. Production and Process Methods ........................................................155

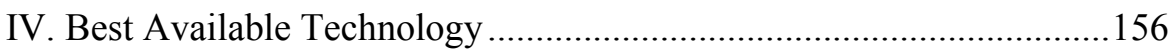

V. Competitive Disadvantage ..............................................................157

VI. Exemption for Developing Countries ..............................................159

A. Intended Beneficiaries of Trade Concessions....................................159

B. Purpose for Exemptions of Developing Countries from Environmental Obligations and BTAs...........................................161

C. Limiting the Availability of Trade Concessions to Intended Beneficiaries

VII. Towards Overcoming the Conflict Between Environmental Tax Leakage and Border Tax Adjustment Concessions for Developing Countries

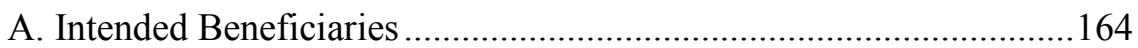

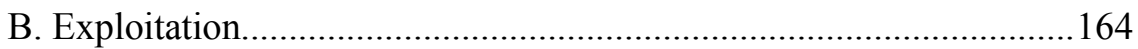

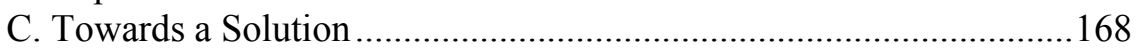

D. Restriction on Relocating Companies .........................................170

E. Residency and Citizenship Requirements....................................171

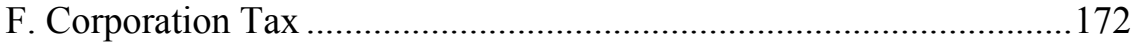

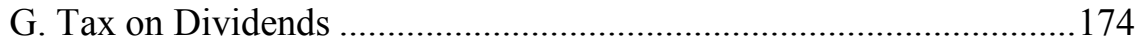

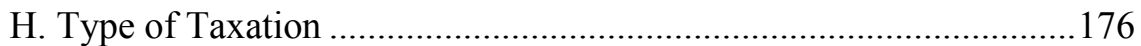

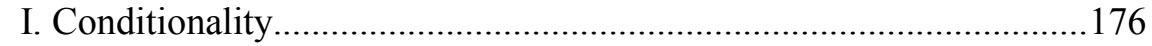

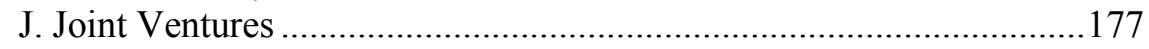

* Doctoral Candidate, Newcastle University Law School, Lecturer in Law, College of Law Qatar University. 


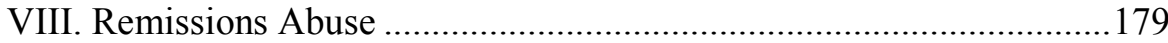

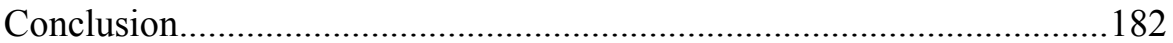

\section{INTRODUCTION}

Border tax adjustments (BTAs) may be able to alleviate concerns of reduced competitiveness for countries introducing environmental taxes and standards, while limiting the risk of companies relocating to developing countries to exploit lax environmental regimes - known as leakage. ${ }^{1}$ However, the ability of industrialized nations to offer developing countries special trade privileges for developmental purposes, including border tariff exemptions on exported goods, provides what is referred to in this article as a "leakage loophole." This scheme allows relocating companies to produce goods in developing countries at high environmental cost and sell them in the industrialized country they relocated from with no adjustment at the border at a potentially lower cost than domestically produced goods which have internalized their negative environmental externalities.

This article considers tax methods that counter the ability of such trade privileges benefitting those wishing to relocate and exploit them as to prevent leakage and ensure any concessions are only available for whom they are intended. In light of current academic debate, this article uses the "best available technology" (BAT) standard to exemplify the potential grounds for adjustment exemption. Further, it considers the uses of border tax adjustments for any legitimate environmental goal, not simply for carbon emissions.

This article is divided as follows, with the presumption that this article applies where World Trade Organization (WTO) law is prevalent. Part I provides a background on unilateral environmental objectives. Part II summarizes reasons why nations may take unilateral action for environmental purposes and how it may impact other nations. Part III introduces the concept of border tax adjustments as a potential trade-neutral environmental measure. Part IV identifies that some environmental taxes may aim to alter the production methods used to make a good instead of concentrating solely upon the environmental qualities of the final product. Part V introduces the notion that any tax incentives used to alter production methods could be dependent upon a producer using the BAT. Part VI

1. See Mustafa H. Babiker, Climate Change Policy, Market Structure, and Carbon Leakage, 65 J. INT'L ECON. 421, 422 (2005) (discussing, in terms of carbon, how developing countries requiring revenue and employment may be willing to allow relocating companies to operate with little environmental supervision). 
explains how nations may withhold the introduction of domestic environmental taxes if they believe it would place their industry at a competitive disadvantage internationally.

Part VII explains that some developing countries' exported goods are exempted from border tariffs upon import into industrialized countries as a form of development aid and also attempts to identify the perceived intended beneficiaries of this aid. Part VII also examines how this exemption offers multi-national enterprises the opportunity to register in developing countries in order to exploit the concession, which is in contradiction of the exemption's intended purpose. Part VIII proposes and critically assesses a number of original solutions to solve this real problem. Finally, this article summarizes and concludes by identifying the most effective solution.

\section{BACKGROUND: UNILATERAL ENVIRONMENTAL OBJECTIVES}

The problem of multi-source locations of negative environmental externalities could most effectively be overcome with coordinated global action. However, political limitations prohibit such a response in the short term; ${ }^{2}$ the pre-Copenhagen negotiations demonstrated that even with a general consensus on an environmental problem, agreement on a multilateral response may prove impossible. The difficulty of a multilateral response is heightened when there are disputes as to the extent of contributions of a source to a problem, ${ }^{3}$ to those who ought to bear the burden of a problem, ${ }^{4}$ to the most effective legal tools of dealing with a problem, ${ }^{5}$ or as to the scientific existence of a problem itself. ${ }^{6}$

2. Jonathan Baert Wiener, Global Environmental Regulation: Instrument Choice in Legal Context, 108 YALE L.J. 677, 696-97 (1999) (explaining that such a response would require "universal or nearly universal coverage of present and potential source locations"); see also Janet E. Milne, New Instruments on Old Turf: The Institutional Challenges of Environmental Taxation, in V CRITICAL ISSUES in Environmental taxation, International and Comparative Perspectives 142 (Nathalie Chalifour et al. eds., 2008).

3. Simon Dresner et al., A History and Social Responses to Environmental Tax Reform in the United Kingdom, 34 ENERGY POL'Y 930, 933 (2006); Dale Jamieson, Uncertainty and Risk Assessment: Scientific Uncertainty and the Political Process, 545 Annals AM. ACAD. POL. \& Soc. SCI. 35, 36-41 (1996).

4. The "Polluter-Pays" principle is exemplified within the Rio Declaration on Environment and Development, which developed a broad understanding of the parties responsible for payment. Rio Declaration on Environment and Development, 31 ILM 874 (1992). For a discussion of who comprises that tax base and whether such parties can be efficiently targeted, see generally MARIE-LOUISE Bemelmans-Videc et al., Carrots, Sticks \& Sermons: Policy Instruments \& their EVAluation (1998); World BanK, EnVironmental Fiscal Reform: What Should Be Done and How TO ACHIEVE IT 22 (2005), available at 
In the absence of coordinated global action, there may be either no international agreement on how to deal with an environmental problem or a multilateral agreement without global coverage. ${ }^{7}$ Some countries may believe that action to protect the environment cannot be postponed pending international consensus and undertake unilateral trade measures, ${ }^{8}$ while

http://siteresources.worldbank.org/INTRANETENVIRONMENT/Publications/20712869/EnvFiscalRef orm.pdf (discussing environmental fiscal reform and the creation of a new tax base); Roberta Mann, Waiting to Exhale?: Global Warming and Tax Policy, 51 AM. U. L. ReV. 1135, 1206-15 (2002) (discussing environmental taxes as a method to reduce greenhouse gas emissions); Paul R. McDaniel, Taxing Consumption Only: Identifying the Issues, 47 TAX EXECUTIVE 442, 442 (1995); R.K. Turner et al., Green Taxes, Waste Management and Political Economy, 53 J. EnVTL. Mgmt. 120, 130-31 (1998) (discussing the benefits of income tax versus consumer tax).

5. Much of the debate began with arguments concerning whether government intervention is appropriate, then considered whether regulation or Pigouvian taxes were the most efficient interventions. See generally Steven N. S. CHeUng, THE MYTH OF Social Cost 67-68 (1978) (discussing the validity of the economic theory of social cost); John M. Keynes, The General TheOry of EMPloyment INTEREST AND MONEY (1936) (discussing the shortcomings of laissez-faire economics); ARTHUR C. Piguo, The ECONOMics of Welfare (4th ed. 1950) (discussing state regulation of the free market); Ping Chen, Complexity of Transaction Costs and Evolution of Corporate Governance, 76 KYOTO ECON. REV. 139, 146-47 (2007) (discussing China's experience in corporate governance); Steven N. S. Cheung, The Fable of the Bees: An Economic Investigation, 16 J.L. \& ECON. 11, 11-13 (1973) (discussing the perils of policy-making); R.H. Coase, The Problem of Social Cost, 3 J.L. \& ECON. 1, 28 (1960) (discussing society's need to account for social costs); Andrew Halpin, Disproving the Coase Theorem?, 23 ECON. PHIL., 321, 321-22 (2007) (discussing the proper application of the Coase Theorem); J. E. Meade, External Economies and Diseconomies in a Competitive Situation, 62 ECoN. J. 54, 58 (1952) (discussing appropriate tax levels to benefit private industry competition). Within those camps lie further debates about the most efficient form of each response, such as the existence of a revenue recycling double dividend. See generally Lawrence H. Goulder, Environmental Taxation and the Double Dividend: A Reader's Guide, 2 INT'L TAX \& PUB. FIN. 157, 157 (1995) (discussing substituting revenue-neutral environmental taxes for income taxes); Wallace E. Oates, Green Taxes: Can We Protect the Environment and Improve the Tax System at the Same Time?, 61 S. ECON. J. 915, 921 (1995). How to correctly value the environment is the subject of further debate. See Dieter Helm \& David Pearce, Assessment: Economic Policy Towards the Environment, 6 OXFORD REv. ECON. POL'Y 1, 2 (1990) (discussing the complexities of creating environmental policies); see generally NICHOLAS STERN, THE ECONOMICS OF Climate Change: The Stern Review 48-49 (2007) (discussing the notion of environmental stewardship in global ethical systems). Milne explains the complexity of the various options such as cap-and-trade policies and carbon taxes. Janet E. Milne, Carbon Taxes in the United States: The Context for the Future, 10 VT. J. ENVTL. L. 1, 22-23 (2008), available at http://www.vjel.org/journal/pdf/VJEL10073.pdf.

6. Due to the complexity of this debate, the debate can only meaningfully be advanced by interdisciplinary research. As such, it is rational to accept as a starting point the current understandings of environmental risk. John Grummer, Climate Change: Global Threat, Global Challenge, 15 NAT. RESOURCES \& ENV'T 156, 156 (2000) (discussing the causes and consequences of global environmental damage).

7. See, e.g., Status of Ratification of the Kyoto Protocol, United NATIONS Framework CONVENTION ON Climate Change, http://unfccc.int/kyoto_protocol/status_of_ratification/items/2613.php (last visited Dec. 7, 2010) (noting the United States' omission to ratify the Kyoto Protocol).

8. Tania Voon, Sizing up the WTO: Trade-Environment Conflict and the Kyoto Protocol, $10 \mathrm{~J}$.

$\begin{array}{llllllll}\text { TRANSNAT'L } & \text { L. } & \& & \text { POL'Y } & 71, & 78 & \text { (2000), available at }\end{array}$ 
others may attempt to incentivize ratification of a treaty by threatening the same to non-cooperating parties. ${ }^{9}$ While parties with such views have a choice of measures to take nationally to achieve unilateral or international environmental objectives, there is a fear amongst those taking such action that their economy will be disadvantaged by imposing higher costs on domestic producers. ${ }^{10}$ Countries introducing internal environmental taxes, regulations, or cap-and-trade schemes ${ }^{11}$ will be concerned that national industries may suffer a loss of competitiveness against similar foreign goods produced without internalizing negative environmental externalities or protecting the environment.

\section{BORDER TAX ADJUSTMENTS}

Border tax adjustments are one possible trade measure to reduce the risk of a market being over-exposed to cheaper, "pollution-intensive imports." ${ }^{12}$ A border tax adjustment is a fiscal measure adopting the "destination principle," which allows:

[E]xported products to be relieved of some or all of the tax charged in the exporting country in respect of similar domestic products sold to consumers on the home market

http://www.law.fsu.edu/journals/transnational/vol101/Voon.pdf; see also Ian Sheldon, Climate Policy and Border Tax Adjustments: Some New Wine Mixed with Old Wine in New Green Bottles?, 11 Esty Centre J. Int'l L. \& Trade Pol'y 253 (2010), available at http://www.esteycentre.ca /journal/j_pdfs/sheldon11-1.pdf) (discussing how the possibility of non-agreement on the Copenhagen Protocol would have lead to countries pursuing differing policies to tackle climate change, resulting in no international price of carbon).

9. Christopher L. Weber \& Glen P. Peters, Climate Change Policy and International Trade: Policy Considerations in the US, 37 ENERGY POL'Y 432, 432-39 (2009) (discussing whether carbon tariffs are the best way to leverage international trade against climate change).

10. For instance, French President Sarkozy has called for BTAs to represent carbon on imports into the European Union to create a fair playing field. Sachin Parashar, France Wants a 'Carbon Tax'on EU Imports, TiMES INDIA (Nov. 30, 2009, 2:00 AM), http://timesofindia.indiatimes.com/india/Francewants-a-carbon-tax-on-EU-imports/articleshow/5282146.cms.

11. "Cap-and-trade" schemes refer to schemes where an authority limits the total permissible quantity of a pollutant. The authority gives allowances to companies specifying the extent to which they may emit the pollutant. Companies not using their allowances may sell them to companies needing more, thereby creating a value for the pollutant. For example, the European Union Emissions Trading Scheme operates such a trading system for $\mathrm{CO}_{2}$ emissions. Council Directive 2003/87, art. 1, 2003 O.J. (L 275) 32 (EC) (establishing a scheme for greenhouse gas emission allowance trading within the community).

12. "Pollution-intensive imports" refers to goods produced using environmental standards falling below, and causing more negative environmental externalities than, similar goods produced in an importing country. In this respect, the term "carbon-intensive" is used to demonstrate a potential shift in consumption. BEN LOCKWOOD \& JOHN Whalley, CTR. FOR INT'L GOVERNANCE INNOVATION, POliCy Brief No. 4: Climate CHANGE-RELATEd Border TAX AdJustMENTS 2 (2008). 
and which enable imported products sold to consumers to be charged with some or all of the tax charged in the importing country in respect of similar domestic products. ${ }^{13}$

Therefore, both exports and imports may be adjusted. In addition to being used to reflect internal taxes, it is also theoretically possible for a border tax adjustment to reflect the internal producer's non-tax costs imposed by regulation or cap-and-trade policies. Their rationale and legality under WTO law are subjects of much study, which is not repeated here. ${ }^{14}$ This article operates on the view that these adjustments are considered legal under specific circumstances, with the caveat that there remains uncertainty in the definitive translation of the relevant international rules. ${ }^{15}$ The basis of the WTO rules on border tax adjustments is that their legitimate purpose is not to limit imports per se, but to limit imports of goods produced using

13. General Agreement on Tariffs and Trade ("GATT")Working Party, Border Tax Adjustments, I 4, L/3464 (Dec. 2, 1970), available at http://www.worldtradelaw.net/reports/gattpanels/bordertax.pdf [hereinafter GATT Working Party].

14. See generally, Steven Bernstein \& Erin Hannah, Non-State Global Standard Setting and the WTO: Legitimacy and the Need for Regulatory Space, 11 J. INT'L L. 575, 591 (2008) (identifying the legal and political dynamics of standards and recognition and finding good prospects for these new nonstate governance systems); Paul Demaret \& Raoul Stewardson, Border Tax Adjustments Under GATT and EC Law and General Implications for Environmental Taxes, 28 J. WORLD TRADE 7 (1994) (discussing GATT and ECU rules); Gavin Goh, The World Trade Organization, Kyoto and Energy Tax Adjustments at the Border, 38 J. WORLD TRADE 395, 395 (2004) (discussing the use of border tax adjustments and implications for WTO Members); Francesco Sindico, The EU and Carbon Leakage: How to Reconcile Border Adjustments with the WTO?, 17 EuR. ENERGY \& ENVTL. L. ReV. 328, 328 (2008) (discussing whether cap-and-trade could be compatible with the law of the WTO).

15. For examinations of the circumstances under which border tax adjustments are considered legitimate, see U.N. EnV'T Programme \& World Trade Org., Trade and Climate Change 103-09 (2009) (discussing whether participation in a cap-and-trade system could "be comparable to a carbon/energy tax for the purpose of introducing border adjustments"); Bradly F. Condon, Climate Change and Unresolved Issues in WTO Law, 12 J. INT’L ECON. L. 895, 898-99 (2009) ("In addition to the foregoing policy alternatives, countries may choose to apply tariffs or border taxes that discriminate between different products based on differences in national climate change policies or differences in the carbon footprints of products, or may provide direct subsidies to domestic producers. The GATT consistency of such border tax adjustments is unclear."); Roland Ismer \& Karstin Neuhoff, Border Tax Adjustment: A Feasible Way to Support Stringent Emission Trading, 24 EUR. J. L. ECON. 137, 137 (2007) (discussing leakage caused by $\mathrm{CO}_{2}$ emission limitations); Stephanie Switzer, International Trade Law and the Environment: Designing a Legal Framework to Curtail the Import of Unsustainably Produced Biofuels, 6 J. INT'L TRADE L. \& POL'Y 30, 30 (2007) (discussing how countries may regulate unsustainably produced biofuels that is consistent with international trade rules); Paul-Erik Veel, Carbon Tarriffs and the WTO: An Evaluation of Feasible Policies, 12 J. INT'L ECON. L. 749, 749 (2009) (examining the legality of cap-and-trade programs under WTO law); John Kemp, Trade Law No Block to Carbon Tariffs, CARBON OFFSETS DAILY (June 26, 2009), http://www.carbonoffsetsdaily.com/ukcarbonmarketnews/trade-law-no-block-to-carbon-tariffs-john-kemp-9280.htm ("Nothing in international trade law would prevent countries that introduce carbon taxes or cap-and-trade programmes from supplementing them with excise duties, tariffs or other measures on imports from countries that don't."). 
standards below those of the importing country so as to provide a level playing field for national producers. ${ }^{16}$ The net result of using these adjustments on trade should be neutral so as not to provide competitive advantages for the importing country. ${ }^{17}$

For the purposes of this article, methods involving taxation are considered, as opposed to non-tax methods such as regulation. ${ }^{18}$

\section{Production AND Process Methods}

Current thought has moved on from the idea that taxes should be placed solely upon environmentally unsound products, despite the relative administrative ease this allows. Taxing a final product based upon its expected negative externalities in order to internalize the environmental cost, however, fails to account for two concerns.

The first concern is that a good may be domestically produced or imported, which is not itself environmentally damaging, but has been produced in an environmentally damaging manner. Since the end-use of such a good is not damaging, it would not ordinarily be taxed. Therefore, it may be necessary to consider the production and process methods (PPMs) used to produce a good. ${ }^{19}$ This can be done by taxing the PPM or taxing the end product to reflect that it was produced using a damaging PPM. The option to tax the end-use of the good remains as a separate tax from the tax based upon its PPMs. For example, a motor vehicle could be taxed to represent its pollution-intensive production method. However, this tax does not exclude the option for policymakers to charge a road user tax or a vehicle excise duty, which aim at different objectives such as incentivizing consumers to purchase vehicles with more efficient engines.

16. For example, the Lieberman-Warner Senate Bill proposed action for countries not taking "comparable action" to America. Lieberman-Warner Climate Security Act of 2008, S. 3036, 110th Cong. $\S 6001$ (2008).

17. The net result may not be trade neutral depending upon market conditions. Steve McCorriston \& Ian M. Sheldon, Market Access and WTO Border Tax Adjustments for Environmental Excise Taxes Under Imperfect Competition, 7 J. PuB. ECON. THEORY 579, 591 (2005).

18. Competing arguments as to which are the most appropriate method are outside the ambit of this article. See Her Majesty's Treasury, Consultations \& Legislation: Review of the $\begin{array}{llllll}\text { TAXATION OF } & \text { ForEIGN } & \text { Profits }\end{array}$ http://webarchive.nationalarchives.gov.uk/+/http://www.hmtreasury.gov.uk/consult_foreign_profits.htm\#primaryContent (reviewing various consultations relating to the taxation of foreign profits).

19. John Whalley, Environmental Considerations in Tax Policy Design, 4 EnV'T \& Dev. ECON. 111, 120 (1999) (discussing the suggested use of PPMs). 
The second concern is the unsatisfactory result of considering only the qualities of a final good. Inputs into a final good may themselves be damaging or have been produced in an environmentally damaging manner. Component parts, known as "intermediary goods," must be accounted forboth intermediary goods which are imported and those which are used in the assembly of final goods before import. ${ }^{20}$ The PPMs of intermediary goods must also be identified; otherwise the full environmental attributes of a good will be ignored. For example, an imported car may be capable of outstanding fuel efficiency and its foreign production plant may assemble the vehicle in an energy efficient manner with all waste recycled. However, assessing the final product does not take into account that many intermediary goods may have been imported from a number of countries, some of which are using unsound PPMs that result in much pollution or environmental destruction. ${ }^{21}$ As such, intermediary goods should be taxed either individually or based upon their input into a final product.

\section{Best AVAILABLE TECHNOLOGY}

The difficulty in using PPMs as a basis for border tax adjustments is in determining what standard should be set for both domestic and imported goods. If the good is non-essential, a nation may decide it can do without it entirely and impose prohibitively high taxes to discourage production, reflected in border tax adjustments. ${ }^{22}$ If the good is essential, or if a nation decides to continue consuming a non-essential good, a nation may decide to implement a standard proposed by Ismer and Neuhoff, which is based upon the use of BAT. ${ }^{23}$ Ismer and Neuhoff's proposal, which was made to limit leakage within an Emissions Trading Scheme ${ }^{24}$ (but which can also be applicable outside an emissions trading scheme), is that adjustments should be determined upon the basis of costs "corresponding to production with

20. Intermediate goods are the subject of the majority of environmental excise taxes. McCorriston \& Sheldon, supra note 17, at 591.

21. James M. Poterba \& Julio M. Rotemberg, Environmental Taxes on Intermediate and Final Goods When Both Can Be Imported, 2 INT'L TAX \& PUB. FIN. 221, 222 (1995).

22. Whether such a restrictive measure would be legal under WTO law would depend upon it being regarded as "necessary to protect human, animal and plant life and health." GATT, art. XX(b), Oct. 30, 1947, 61 Stat. A-11, 55 U.N.T.S. 194 [hereinafter GATT]. It would also depend on being "related to the protection of exhaustible natural resources." GATT art. XX(g); see Alex Young, WTO and Integrated Product Policy (IPP): Trade Law Implications for the Use of Product Policy Instruments to Reduce the Risk of Exposure and Harm from Hazardous Substances in the Life Cycle of Personal Computers, $9 \mathrm{~J}$. Cleaner Production 297, 299 (2000) (discussing what would constitute "necessary" or "related to").

23. Ismer \& Neuhoff, supra note 15, at 140.

24. Milne, supra note 5, at 3. 
BAT rather than average technology." 25 This system has similarities with the United States' proposed economic incentives for retailers selling "Bestin-Class Appliances" to improve household efficiency, pursuant to the American Clean Energy and Security Act of 2009. ${ }^{26}$

If such technology is commercially available ${ }^{27}$ on the market and can be produced in the most efficient manner possible at any one time, producers will only be able to get border-tax-adjustment reimbursements if they use such technology. This could create demand for clean technology and provide a continuing incentive to innovate, which consequently may lead to a technology-driven response to environmental protection. ${ }^{28}$ Even Dowell, Hart, and Yeung, who argue against the risk of leakage, advocate innovative clean technology as being able to "achieve simultaneously world-class cost, quality, and environmental performance." 29 Though difficulties have been highlighted in requiring BAT, the BAT-Border-Tax-Adjustment method will be considered henceforth as a basis for exempting imports from these adjustments to exemplify the "leakage loophole" problem. ${ }^{30}$

\section{COMPETITIVE Disadvantage}

A potential disadvantage in countries with environmental taxes is that consumption may shift to pollution-intensive imports. Any tax situation which would allow nations to benefit from their omission to internalize environmental negativities could be both environmentally and economically counter-productive. If mobile taxpaying industries relocate to pollution

25. Ismer \& Neuhoff, supra note 15 , at 140.

26. American Clean Energy and Security Act of 2009, H.R. 2454, 111th Cong., § 214 (2009).

27. In practice, this means being available to buy on the open market, preferably from a range of competitive sellers as opposed to only being available in countries requiring its use. This could cause a country to exploit its ability to offer trade concessions in order to increase sales of its domestically produced technology. EMP.-INTENSIVE INVESTMENT BRANCH, INT'L LABOUR ORGANISATION, A Global Programme: INVESTING IN EMPLOYMENT FOR POVERTy REDUCTION AND LOCAL ECONOMIC $\begin{array}{lll}\text { GROWTH } & 12 & \text { (2003), }\end{array}$ http://www.ilo.org/public/english/employment/recon/eiip/download/eiip_prodoc.pdf [hereinafter A GLOBAL PROGRAMME].

28. Ismer \& Neuhoff, supra note 15, at 155 (discussing the potential for BAT requirements to incite innovation).

29. Glen Dowell et al., Do Corporate Global Environmental Standards Create or Destroy Market Value?, 46 MGMT. SCI. 1059, 1060 (2000).

30. See Bernstein \& Hannah, supra note 14, at 591 (discussing the difficulties related to requiring BAT as a basis for border tax adjustments); Reinhard Quick \& Christian Lau, Environmentally Motivated Tax Distinctions and WTO Law: The European Commission's Green Paper on Integrated Product Policy in Light of 'Like Product-' and 'PPM-'Debates, 6 J. INT'L Econ. L. 419, 432-33 (2003) (same). 
haven countries that offer little environmental regulation or taxation, ${ }^{31}$ then an environmentally conscious country could lose valuable industries and their receipts, while no overall environmental benefit would accrue, as the industry may continue, or even increase levels of pollution overseas. ${ }^{32}$

Though some have suggested there is no benefit to be gained in practice for a country offering lax environmental regimes, ${ }^{33}$ the economics are uncertain, ${ }^{34}$ and the prospect of a possible competitive disadvantage may itself discourage countries from utilizing eco-taxes. ${ }^{35}$ In those countries introducing environmental taxation there is the risk that companies

31. Foreign direct investment in developing countries was found to be "relative to the stringency of their environmental regulations." Robert J. R. Elliott \& Kenichi Shimamoto, Are ASEAN Countries Havens for Japanese Pollution-Intensive Industry?, 31 WORLD ECON. 236, 250 (2008) ("Pollution-intensive [foreign direct investment] will be drawn to countries with a high level of capital endowment relative to the stringency of their environmental regulations.").

32. The actual consequences of leakage will differ depending upon the industry sector involved and may not apply to every sector; a study into the cement industry, for example, showed that there was a significant danger of leakage causing a rise in global emissions without border tax adjustments. Damien Demailly \& Philippe Quirion, Leakage from Climate Policies and Border Tax ADJUSTMENT: LESSONS FROM A GEOGRAPHIC MODEL OF THE CEMENT INDUSTRY (2006), available at http://halshs.archives-ouvertes.fr/docs/00/06/01/89/PDF/cement_industry.pdf.

33. Multi-national corporations adopting poor environmental standards of host countries do not increase their net worth and are generally valued financially lower than environmentally proactive companies. This happens for a number of reasons including not utilizing innovative technology, lower morale amongst workers disaffected by the environmental standing of their country, and negative reputation and costs caused by protesters. Dowell et al., supra note 29, at 160. Environmental standards in a country can actually increase innovation which would be beneficial to an economy. Michael E. Porter \& Claas van der Linde, Toward a New Conception of the Environment-Competitiveness Relationship, 9 J. ECON. PERSP. 97, 98 (1995). There is also the prospect of the exchange rate mechanism operating to negate any advantage and the balance of payments cancelling out such benefits. See, e.g., Gene M. Grossman, Border Tax Adjustments: Do They Distort Trade?, 10 J. InT'L Econ. 117, 118 (1980) (discussing comparative advantages); Harry G. Johnson \& Mel Krauss, Border Taxes, Border Tax Adjustments, Comparative Advantage, and the Balance of Payments, 3 CANADIAN J. ECON. 595 (1970) (same).

34. Organisation for Economic Co-operation and Development (OECD) studies have found little evidence of environmental taxes causing competitive disadvantages for industry, though national concessions made to industry could distort their effectiveness. See ORGANISATION FOR ECON. COOPERATION \& DEV., ENVIRONMENTALly RELATED TAXES: ISSUES AND STRATEGIES 4 (2001), available at http://www.oecd.org/dataoecd/39/18/2674642.pdf ("To date, environmentally related taxes currently imposed by OECD countries have not been identified as causing significant reductions in the competitiveness of any sector."). Competitiveness Effects of Environmental Tax Reforms (COMETR) is a European research project which studies the competitive effects of eco-taxes by sector. COMPETITIVENESS EFFECTS ENVTL. TAX ReFORMS, http://www2.dmu.dk/cometr (last updated Mar. 26, 2007). It has also been reported that in Canada between 2007 and 2008, GDP actually grew half a percent while emissions fell by nine percent among the top ten largest Canadian polluters. Canada's Biggest Polluters Slash Emissions, CORP. KNIGHTS (Dec. 16, 2009), http://www.corporateknights.ca/inthe-press/72-press-releases/512-canadas-biggest-polluters-slash-emissions.html.

35. This is referred to as the "regulatory chill." Ian Sheldon, Trade and Environmental Policy: A Race to the Bottom?, 57 J. AgRic. ECON. 365, 368 (2006). 
exploiting pollution havens' lax rules to produce at a low cost could then export goods back to the market they relocated from, in order to undercut goods produced under stricter environmental rules - a process known as "environmental dumping." ${ }^{36}$ Border tax adjustments would ordinarily operate to prevent such goods from entering a market at a low cost and thus remove the incentive for leakage. However, a potential problem arises when concessions are made for developing countries for developmental purposes and companies seek to exploit this.

\section{EXEMPTION FOR DEVELOPING COUNTRIES}

The preventative ability of border tax adjustments in deterring environmental dumping and leakage is diluted by the perceived desirability of aiding developing countries via trade concessions. The purpose of these concessions will briefly be identified in the first subpart of this Part, together with a summary of how such concessions can be made under WTO law. This Part emphasizes that such concessions should be made only for developing countries, and not foreign private enterprises. Part VIII explains the potential for exploitation of the concession.

\section{A. Intended Beneficiaries of Trade Concessions}

The WTO employs a number of methods to alleviate poverty issues and aid development in developing countries, one of which is encouraging nonreciprocal trade concessions with industrialized Countries. ${ }^{37}$ By gaining access to markets in industrialized countries without paying import tariffs or other such charges, employment and trade opportunities can be created in developing countries that can encourage economic growth, thereby reducing poverty and dependence on direct foreign aid. This article accepts the proposition that trade concessions of this form are a beneficial approach. Normally, any preferential trade advantage offered to one nation must be offered to all nations pursuant to the "Most Favored Nation" principle, to prevent discrimination between different foreign producers. ${ }^{38}$ However, the

36. U.N. ENV'T PROGRAMme \& WORLD TRADE ORG., supra note 15, at 103-09.

37. The principle requires that any trade advantage offered to one WTO member must be extended to all members to prevent discrimination. WORLD TRADE ORG., UNDERSTANDING THE WTO

93-94 (5th ed. 2010), available at http://www.wto.org/english/thewto_e/whatis_e/tif_e/understanding_e.pdf.

38. General Agreement on Tariffs and Trade 1994, (Marrakesh, Morocco, 15 April 1994), Marrakesh Agreement Establishing the World Trade Organization, Annex 1A; THE LEGAL TEXTS: THE 
Generalized System of Preferences permits non-reciprocal trade concessions between industrialized countries and developing countries, offered by the former on a more favorable basis than they offer other nations, if they are "designed to facilitate and promote the trade of developing countries." " This is known as the "Enabling Clause." ${ }^{40}$ There is no requirement for such trade preferences to be offered to all developing countries; the special treatment can be granted to specific countries on the objective perception of their development needs. ${ }^{41}$

The rationale for permitting trade concessions in favor of developing countries was determined at the second United Nations Conference on Trade and Development (UNCTAD) conference in 1968. ${ }^{42}$ The agreed purposes were that such measures must be designed to promote industrialization, increase export earnings, and accelerate the rate of economic growth in developing countries. ${ }^{43}$ Accordingly, the intended beneficiary of such trade concessions is the economy of a developing country and not any private enterprise or outside government. The Enabling Clause is a special measure designed to assist very poor countries under extraordinary circumstances. Therefore, it is important to acknowledge upon whom its benefits should fall. We can thus assert that the profits ${ }^{44}$ from the Enabling Clause were intended solely to benefit the people and overall society of developing countries via an improved economy and not any outside interests.

For example, the European Union (EU) has a system of tariff preferences which allow certain developing countries to import goods into the EU on a duty-free, quota-free basis, to aid development. ${ }^{45}$

Result of the Uruguay Round of Multilateral Trade Negotiations 17 (1999), ARt. I:1, 1867 U.N.T.S. 190, 33 I.L.M. 1153 (1994).

39. Decision of the Signatories, Differential and More Favourable Treatment Reciprocity and Fuller Participation of Developing Countries, cl. 3(a), L/4903 (Nov. 28, 1979) GATT B.I.S.D. (26th Supp.) at 191-92 (1980), available at www.wto.org/english/docs_e/legal_e/tokyo_enabling_e.pdf.

40. Work on Special and Differential Provisions, WORLD TRADE ORG., http://www.wto.org/english/tratop_e/devel_e/dev_special_differential_provisions_e.htm (last visited Dec. 7, 2010).

41. Appellate Body Report, European Communities - Conditions for Granting of Tariff Preferences to Developing Countries, $\uparrow 163$, WT/DS246/AB/R (Apr. 7, 2004).

42. About GSP, U.N. CONFERENCE ON TRADE AND DEV. (2002), http://www.unctad.org/templates/Page.asp?intItemID=2309\&lang=1.

43. U.N. CONFERENCE ON TRADE AND DeV., THE History OF UNCTAD 1964-1984 at 58-59, U.N. Doc. UNCTAD/OSG/286 (1985).

44. This is not referring to the general economic benefits such as increased employment, but with the further financial benefits namely the monetary profits.

45. Council Regulation 732/2008, 2008 O.J. (L 211) 2 (EC), available at http://eurlex.europa.eu/LexUriServ/LexUriServ.do?uri=OJ:L:2008:211:0001:0039:EN:PDF. 


\section{B. Purpose for Exemptions of Developing Countries from Environmental Obligations and BTAs}

Developing countries are sometimes exempted from environmental obligations in order to enable them to focus upon their own development needs in the short term, despite the pressing need for compliance with environmental objectives. International law permits some such exceptions due to the gravity of potential economic and social harm that could be imposed by ensuring the poorest developing countries put environmental targets above alternative goals such as providing food, water, and medicine. WTO Member States whom the UN name as "Least Developed Countries" 46 can be given more time before they are obliged to meet the same obligations as other States. The Agreement on Subsidies and Countervailing Measures ${ }^{47}$ permits "Special and Differential Treatment" that exempts these countries from obligations on phasing out export subsidies and provides further time for certain developing countries (and transition economies) to achieve agreed standards. ${ }^{48}$ The United Nations Framework Convention on Climate Change (UNFCCC) ${ }^{49}$ and Kyoto Protocol ${ }^{50}$ categorize signatories based upon economic development; while all parties have responsibilities, only industrialized countries committed to greenhouse gas (GHG) measures have emissions-reduction requirements. Further, the EU pays particular attention to the capabilities of least developed countries and recognizes the principle of "Common but Differentiated Responsibilities." ${ }^{\text {, }}$

The justification for allowing goods exported from developing countries to be exempted from border tax adjustments follows from the general justification of exempting them from border tariffs. If the standard that developing countries must adopt to avoid paying border tax adjustments is the use of BAT, this can pose serious problems for these

46. "Least Developed Countries" are often those whose GNP per capita is lower than USD $\$ 1000$ per annum. What are the Least Developed Countries (LDCs)?, United NATIONS (June 2004), http://www.un.org/geninfo/faq/factsheets/FS20.HTM.

47. Agreement on Subsidies \& Countervailing Measures art. 27, Apr. 15, 1994, Marrakesh Agreement Establishing the World Trade Organization, Annex 1A, 1867 U.N.T.S. 14

48. Id.

49. United Nations Framework Convention on Climate Change, Mar. 21, 1994, 1771 U.N.T.S. 107, available at http://treaties.un.org/doc/Treaties/1994/03/19940321\%200456\%20AM/Ch_XXVII_07p.pdf.

50. Kyoto Protocol to the United Nations Framework Convention on Climate Change, art. I, 1 7, adopted Dec. 11, 1997, 37 I.L.M. 22 (entered into force Feb. 16, 2005).

51. Proposal for a Directive of the European Parliament and of the Council Amending Directive 2003/87/EC so as to Improve and Extend the Greenhouse Gas Emission Allowance Trading System of the Community, at 8, COM (2008) 16 final (Jan. 23, 2008). 
countries. For those developing countries whose economies are dependent upon industrialized countries' consumption of their exports, the prospect of changing their PPMs to BAT may cause concern because of the incompatibility of those production methods to their development goals. Many developing countries aim for labor-intensive industries rather than BAT in order to create employment, and such technology may not only create unemployment but may need to be imported from an industrialized country at high cost. ${ }^{52}$ Aside from being allowed to export without border tax adjustments, the capital expenditure of the BAT plus technical experts (possibly foreigners) to operate and repair the technology and train locals on its usage, may serve no economic or social needs for the developing country and may hinder other development needs. Further, if the environmental problem to be corrected is localized in the industrialized country using border tax adjustments, the developing country may see no environmental benefits internally from using BAT.

Imposing environmental requirements, such as BAT with which exporting developing countries must comply to avoid the border-taxadjustment charge, has thus been referred to as "eco-imperialism." ${ }^{, 33}$ Rather than using border tax adjustments to force developing countries to comply with environmental obligations, the stance accepted herein is that trade concessions, including the exclusion of these adjustments for imports from certain developing countries, should be avoided in order to promote economic development. The environmental goals, which would ordinarily necessitate border tax adjustments, can instead be achieved in developing countries via subsidies and assistance from their industrialized partners. ${ }^{54}$

\section{Limiting the Availability of Trade Concessions to Intended Beneficiaries}

Nevertheless, since this means that pollution-intensive imports may be able to compete with goods produced using BAT, it is important that: (a) such concessions are made only in the short term until a developing country develops the capability to produce goods using BAT, via subsidies and technical assistance from industrialized countries; and (b) the quantity of pollution-intensive imports reflects only the intended beneficiaries. This latter point is crucial since an industrialized country's market could become

52. See A Global Programme, supra note 27, at 10.

53. Mia Shanley \& Iona Wissenbach, Germany Calls Carbon Tariffs "Eco-Terrorism," REUTERS, July 24, 2009, http://www.reuters.com/article/idUSTRE56N1RJ20090724.

54. Frank Biermann \& Rainer Brohm, Implementing the Kyoto Protocol without the USA: The Strategic Role of Energy Tax Adjustments at the Border, 4 CliMATE POL'Y 289, 291 (2005). 
saturated with pollution-intensive imports, causing significantly reduced demand for goods produced using BAT. This risk exists where there is the possibility of the benefit of the trade concessions falling outside of the intended beneficiaries - namely into the hands of foreign private enterprise. A Multi-National Enterprise (hereinafter, "enterprise") operating within a developing country could utilize its trade concessions to produce pollutionintensive exports for sale in an industrialized country below the cost of BAT-produced goods. Though the developing country's export earnings would be increasing, the profits may leave the developing country and mainly benefit shareholders in industrialized countries.

Prima facie, this would appear not to infringe upon the given purpose of non-reciprocal trade concessions. Export earnings could increase in developing countries and there may be some employment and economic development: however, the practice of enterprises benefiting from such trade concessions goes against the spirit of the concessions for two fundamental reasons.

The first reason is that the concessions are designed to benefit the economy of a developing country. If profits are leaving the country, then the extent of the economic benefit to the developing country is reduced. Although jobs may be created and factories may be built, if the full benefits went to the intended beneficiaries, then there may be significantly greater economic development, with profits being reinvested into the economy and the country's net wealth increasing. In this way, the economy can graduate into an industrialized economy, rather than remaining developing. Importantly, enterprises should not be discouraged from investing in developing countries and creating growth there, but in this special circumstance it is crucial that the concessions create as much growth for the intended beneficiaries as possible.

The second reason is that it is inequitable for industrialized countries to provide this form of development aid, only for it to benefit private parties outside of the intended beneficiary, the developing country. The Enabling Clause allows nations to discriminate, where normally they cannot, for the purpose of benefiting a developing country's economy. Therefore, gaining a private advantage through this charitable provision is exploitation and can prevent the benefit from being utilized by those for whom it was intended.

Furthermore, the negative impact on an industrialized country's economy could be worsened if, as mentioned, an enterprise has an incentive to mass produce pollution-intensive goods, damaging domestic manufacturing that only had been prepared to bear a minimal burden to aid developing countries. At the same time, the environmental impact caused by an enterprise's expansion of pollution-intensive production in a 
developing country could be significant, negating any benefit of an industrialized country's internal environmental taxation.

\section{TOWARDS OVERCOMING THE CONFLICT BETWEEN \\ ENVIRONMENTAL TAX LEAKAGE AND BORDER TAX ADJUSTMENT CONCESSIONS FOR DEVELOPING COUNTRIES}

\section{A. Intended Beneficiaries}

Having determined the limited parties whom the Enabling Clause was intended to benefit, and the inequitable position of allowing outside parties to benefit, it is important next to consider the potential for exploitation of these rules. Following this explanation, potential solutions to the stated problem will be explored.

\section{B. Exploitation}

A possible exploitation of the rules by corporations is not just leakage, but using the Enabling Clause as a loophole - a potential problem which remains unexplored. An industrialized counry would intend that the existence of border tax adjustments would remove the incentive for an enterprise to relocate to another country to take advantage of the latter's lax environmental rules and thereby lower its costs. ${ }^{55}$ However, a problem arises when the enterprise relocates (in all or part) from an industrialized to a developing - or least developed - country that has non-reciprocal tariff preferences with that industrialized country. Under such circumstances, exports from the developing country may not be subjected to border tax adjustments.

Therefore, an enterprise could produce its pollution-intensive goods in a developing country and export them without paying a border tax adjustment to an environmentally-stringent industrialized country. ${ }^{56}$ This possibility puts the industrialized country at the potential disadvantage of having pollution-intensive goods undercut those goods produced with BAT. While the purpose of the Enabling Clause is to provide a form of development aid to developing countries, ${ }^{57}$ this scenario is an indirect

55. Jane G. Gravelle, Tax Havens: International Tax Avoidance and Evasion, 62 NAT'L TAX J. 727, 727 (2009) (explaining the means in which enterprises utilize tax havens to avoid tax).

56. Erik Levinson, Offshoring Pollution: Is the United States Increasingly Importing Polluting Goods?, 4 REV. ENVT'L ECON. \& POL'Y 63, 74-77 (2010) (discussing recent studies suggesting U.S. offshoring is creating pollution).

57. Appellate Body Report, supra note 41, $\mid 168$. 
subsidy to enterprises who would be benefiting at the expense of both the environment, where their negative externalities are not accounted for, and environmentally-conscious producers using BAT. In this instance, the profits would not be going to the intended beneficiaries in developing countries, but to the shareholders of enterprises who may still be based in the industrialized country.

The pressure upon enterprises to exploit the tax system in this manner arises from their aim of mitigating costs to maximize profits. Such a cost reduction could not only help to reduce costs, but could place pollutionintensive goods at a cost advantage over goods produced using BAT and sold in an industrialized country. Thus, shifting demand towards the pollution-intensive goods, increasing sales and providing enterprises with a distinct incentive to continue profiting in this tax-avoiding manner.

\section{Examples}

The examples below demonstrate the potential risks, using the hypothetical as follows:

The United Kingdom (UK) introduces an internal environmental tax on the production of final and intermediary goods. This is coupled with a border tax adjustment to represent the amount that imports would have been taxed had the import been produced under the UK's environmental production tax. Production using BAT is tax-exempt, and imports certifying that they were produced using BAT do not have to pay any border tax adjustment.

Y-Co. is a yacht manufacturer based in the UK.

T-Co. is a producer of final and intermediary goods based in Tanzania.

The UK offers trade concessions to Tanzania, a least developed country, in the form of an exemption from any border tariffs, including border tax adjustments. In this example, Tanzania does not have the capability to produce using BAT.

Intermediary goods and final goods imported to the UK must carry a certificate of origin. 


\section{Example 1}

Y-Co. imports intermediary goods for use in the assembly of yachts from T-Co. because they are less expensive than intermediary goods produced in the UK.

Y-Co. then sells its final product in the UK at a cost of $£ 200,000$.

Yacht producers who sourced all of their intermediary goods from those producers using BAT sell similar yachts in the UK for $£ 220,000$. The extra cost reflects the high cost to manufacturers of intermediary goods of purchasing and operating BAT. Manufacturers of intermediary goods not using BAT, based in the UK or a country without trade concessions with the UK, sell goods at a higher price due to the additional tax charged upon the non-use of BAT. Producers sourcing goods from such manufacturers sell similar yachts in the UK for $£ 250,000$. Consequently, Y-Co. has the advantage because it purchases intermediary goods from Tanzania.

In this example, although Y-Co. is benefiting from the tax model at the expense of the environment, this will not infringe upon the purposes of the Enabling Clause if T-Co.'s profits remain in Tanzania.

Since the final good is assembled in the UK, whether there is a charge to environmental production tax will depend upon whether it is assembled using BAT. In this way, the only goods produced without BAT and not attracting the tax, are those produced in Tanzania, and the main purpose should be to benefit the Tanzanian economy.

\section{Example 2}

T-Co. exports its own final products to a buyer in the UK, who sells the yachts in the UK for a profit.

Given that T-Co.'s profits remain in Tanzania, there is no infringement of the Enabling Clause, and the purpose is fulfilled because exports rise and the Tanzanian economy benefits.

\section{Example 3}

Y-Co. moves its manufacturing process from the UK to its subsidiary company, Z-Co., in Tanzania. Z-Co. produces yachts in Tanzania and exports them back to the UK for sale. Z-Co. can then sell yachts in the UK below the cost of yachts produced using BAT. Profits of the sale are transferred from Z-Co. to Y-Co.

Although this does not breach the letter of the law, it goes against the purpose of the Enabling Clause. Since Y-Co. retains the profits in the UK, there is insufficient economic benefit for Tanzania to justify the concession 
from the UK's perspective. This is further the case when the profits are not returned to the UK but to a competitor industrialized country.

Furthermore, since the manufacturing has taken place in Tanzania and not the UK, not only has the UK lost employment and tax revenue, but it has lost the ability to regulate the environmental externalities caused during manufacturing.

\section{Example 4}

Y-Co. acquires T-Co. Y-Co. produces all of its intermediary goods in the UK without using BAT and is charged an environmental production tax. However, upon export, this tax is remitted to Y-Co. as a border tax adjustment. Y-Co. exports the intermediary parts to T-Co. for assembly. Within Tanzania, there is minimal assembly required. Y-Co. then imports the final product from T-Co. for sale in the UK.

In this situation, which goes against the spirit of the concessions of the Enabling Clause, origin requirements would prevent the concession being granted upon the yacht's import into the UK. Origin requirements mean that a country benefiting from trade preferences must wholly or substantially produce the goods so that they cannot undergo only a small amount of processing in such a beneficiary country. ${ }^{58}$ Goods must be wholly or substantially produced in the beneficiary country for them to achieve the border-tax-adjustment exemption, which is reasonable because otherwise there would be little benefit to the developing country and only the enterprise would benefit.

The same result would apply if the intermediary goods were substantially imported from third-party countries.

\section{Summary of Unintended Beneficiary Problem}

The rules on non-reciprocal trade preferences do not explicitly prohibit enterprises from profiting from trade concessions. Indeed, some industrialized countries allow enterprises based within their jurisdiction to profit from the concessions they make to developing countries. ${ }^{59}$ However, for an industrialized country intending for the benefits of its concessions to assist the economy of a developing country to the maximum extent possible, without providing benefits to those outside of the developing country, such

58. Bonapas Francis Onguglo, Developing Countries and Unilateral Trade Preferences, in TRAde Rules In the MaKing: Challenges in Regional and Multilateral NegOtiations 114-18 (Miguel Rodriguez Mendoza et al. eds., 1999).

59. Id. at 120 . 
an industrialized country will need to consider methods to attach to its border tax adjustments to prevent any benefit-namely profits-from leaving the developing country. The methods discussed below will attempt to find a watertight solution to ensure foreign enterprises, particularly enterprises, do not exploit the provisions of the Enabling Clause. ${ }^{60}$

\section{Towards a Solution}

Finding a solution involves first ascertaining what legal capabilities an industrialized country has to alter PPMs outside its jurisdiction. A sovereign country has the sole right to prohibit a company based within its own jurisdiction from producing and selling pollution-intensive goods within that jurisdiction. Unilateral actions of an environmentally concerned industrialized country can only assert pressure on a developing country, or its domestic enterprises, to change internal PPMs. However, a concerned industrialized country has much more control over the environmental qualities of what it imports. This can be done by ascertaining the origin of imported intermediary or final goods in order to determine whether such products can be sold within an industrialized country's jurisdiction.

A producing company based within a developing country may also be a subsidiary of a company based within an industrialized country — or may be owned (partly or wholly) by private or corporate shareholders resident in an industrialized country. By identifying the ultimate shareholders of such a company, the benefiting parties can be determined. Since the purpose of the Enabling Clause is for residents of developing countries to benefit for development purposes, it is important that shareholders based within industrialized countries are not the beneficiaries. This would promote leakage.

To determine whether the appropriate beneficiaries are benefiting, the stance will be adopted that non-residents of a developing country should not be the main beneficiaries. Therefore, the objective is to ensure that any enterprise benefiting from the concession is substantially owned by residents of developing countries. This is not a perfect solution because there is no guarantee that the wealth will be distributed within that country; however, since the wealth remains within the developing country, rather than being distributed abroad, it is as far as the objective can go to ensure the purposes of the concessions are carried out.

60. See Gaëtan Nicodème, On Recent Developments in Fighting Harmful Tax Practices, 62 NAT'L TAX J. 755, 760 (2009) (discussing general methods to prevent exploitative tax practices elsewhere). 
Furthermore, while developing-country enterprises are not being punished by industrialized countries with tariffs they are unable to afford for not using BAT, it is also the case that pollution-intensive capabilities within developing countries should not be overly encouraged. Foreign investment could encourage pollution-intensive capabilities within developing countries, which is why benefits to enterprises are discouraged. The idea of the concessions is to allow developing countries to benefit in the short term to avoid catastrophic social and economic consequences caused by losing export revenue, until such assistance is provided to developing countries enabling them to operate using BAT. As such, the reasoning is that an industrialized country will allow a developing counterpart to compete in their territory using non-BAT PPMs in their exports, but will not help them to expand their non-BAT PPM capabilities. This limited assistance rationale means that enterprises should not be shareholders of non-BAT developing country enterprises claiming the border-tax-adjustment concession, should not be involved in such joint ventures, and should not provide funding to develop non-BAT PPM capabilities. The import of non-BAT produced goods for sale in industrialized countries is the appropriate level of assistance to developing countries. As such, "substantial" should mean that enterprises within a developing country claiming border-tax-adjustment concessions must be wholly owned by residents of the developing country and no one else. Admittedly, this may prevent occurrences where a small amount of foreign assistance could cause a large benefit. Only with such a stringent rule can any incentive to exploit the concession be removed (though this is examined further when looking at joint ventures at Part VII.J.). Incentives should instead be used within industrialized countries to expand BAT capabilities within developing countries in order that there remains an incentive to invest in these developing nations, but for the right reasons.

The various solutions are considered below using the following assumed terminology relevant to the hypothetical scenarios discussed:

- Ecoland: an industrialized country with stringent environmental regulations or taxation, with border tax adjustments on imports unless BAT is used;

- Developa: a "pollution-haven" developing country with non-reciprocal tariff preferences with Ecoland amounting to an exemption from BTAs for exports;

- X-Co.: an enterprise registered in Ecoland with customers in Ecoland, intending to relocate parts of its 
business operations to Developa to produce without using BAT and export those goods from Developa for sale in Ecoland; and

- Sub-Co.: a company registered in Developa and not using BAT.

For descriptive purposes, the following solutions will utilize limited companies as the chosen business model of an enterprise, other than the discussion of joint ventures at Part VII.J. However, the following solutions can also be adapted to apply to other forms of business, such as sole traders, partnerships, and public limited companies.

\section{Restriction on Relocating Companies}

One option would be to impose a restriction on companies relocating to Developa in order that companies relocating from outside Developa would not be able to take advantage of border-tax-adjustment concessions with Ecoland. However, there is the serious practical problem of how to determine whether a company is "relocating." Companies forming in Developa could be either the continuing business of a company relocating from Ecoland, or a business entirely formed in Developa without foreign interest, or a mixture of both. The complexities of determining whether a company in Developa is a relocated company would be highly impractical.

One means of preventing relocation would be to restrict the concession to only existing companies in Developa. However, this could still mean that any foreign-owned (or partially owned) companies who were operating in Developa prior to this restriction could continue to profit. It would create incentives for shareholders to invest in such companies since they would have economic advantages over other newly-formed or newly-relocated companies. This could prove anti-competitive in Developa's internal market, creating monopolistic corporations who attract much foreign investment. In such a scenario, non-developing-country investors could continue to profit while the environment might suffer further with large market forces created through an existing developing-country company's export rights. Equally, a small number of large producers could sell their products at costs below the costs of similar goods in Ecoland, thereby damaging Ecoland's economy and environmental objectives. Therefore, such an option is highly impractical. 


\section{E. Residency and Citizenship Requirements}

An alternative means of closing access to the border-tax-adjustment concession to X-Co. is to restrict its use only to companies wholly owned by shareholders resident in Developa. It is important that such companies could not be subsidiaries of other companies, unless those companies are also wholly owned by shareholders resident in Developa. In doing this, Ecoland would not put its shareholders at a disadvantage against other industrialized countries who could otherwise become shareholders in Developa's companies.

In order to restrict the concession to the intended beneficiaries, it would be necessary to identify whether a Developa company is owned by shareholders who are resident, ordinarily resident, or domiciled in Developa (assuming that Developa's tax system has a similar legal meaning of these terms as in the UK). With such requirements, the shareholder must have established a permanent presence in Developa and be paying tax within that jurisdiction. Any foreign national wanting to relocate to take advantage of Developa's trading rights would need to be physically present, reside in Developa, and pay tax there. This requirement to relocate, coupled with the time requirements and procedural difficulties to gain residency in Developa, may sufficiently deter those only seeking to exploit trade privileges.

A tighter version of this rule would only permit companies with shareholders with citizenship in Developa to take advantage of this concession. Since citizenship is generally more difficult to gain than a residency permit, it is a more certain indication that the beneficiary intends to remain in Developa. For example, in the United Republic of Tanzania it is not possible to gain dual-citizenship, so an alien would need to renounce any previous citizenships ${ }^{61}$ have lived there for eight years, speak English or Kiswahili, and intend to continue to reside permanently in Tanzania. ${ }^{62}$

This would not deter ordinary foreign direct investment into Developa, other than investment for the purpose of exploitation of the border-taxadjustment concession. Such a provision can be a permissible condition following EU Tariff Preferences, which allows the Enabling Clause to be designed towards the development needs of a developing country. ${ }^{63}$

61. Tanzania Citizenship Act of 1995, 6, Oct. 10, 1995 (United Republic of Tanzania), available at http://www.unhcr.org/refworld/docid/3ae6b5734.html (last visited Jan. 9, 2011).

62. Id. at 2 d sched. $\S 9(1)$.

63. Appellate Body Report, supra note 41, ๆ 162 (discussing that treatment of "developing countries" may be different). Paragraph 168 highlights 93 (c) of the Enabling Clause which requires Enabling Clause treatment to be "designed and, if necessary, modified, to respond positively to the development, financial and trade needs of developing countries." Id. $\mid 168$. 
This provision would not enable joint ventures with individuals or companies from outside Developa to become a beneficiary of the bordertax-adjustment concessions. The following solutions are developments of this proposed solution.

\section{F. Corporation Tax}

Another solution is to charge a corporation tax surcharge upon X-Co. Since X-Co. is registered in Ecoland, it is possible to tax X-Co.'s foreign assets. The surcharge would become chargeable in Ecoland based upon any foreign assets of X-Co. that are not produced using BAT. The incentive would therefore be for X-Co. to ensure that all of its foreign companies within its group would use BAT, since it would otherwise be taxed within Ecoland. In order that companies would not be discouraged from remaining registered within Ecoland, a parallel corporation tax incentive could be offered to companies registered within Ecoland whose foreign assets produce using BAT - such as a corporation tax rebate or deferral.

Therefore, if Sub-Co. was a subsidiary of X-Co., X-Co. would be liable for a surcharge since Sub-Co. produces using non-BAT methods. In this manner, Ecoland is able to extend its environmental influence outside of its borders to encourage improved PPMs and remove the incentive for enterprises to exploit trade concessions if they wish to continue having access to Ecoland's market. The result of such a policy is even more farreaching. Even if Sub-Co. only produced and sold goods within Developa, $\mathrm{X}-\mathrm{Co}$. would still be subject to a surcharge because it owns Sub-Co.

To enable a level playing field for Ecoland's domestic companies, the corporation tax surcharge would not only fall upon X-Co., but it would also fall upon any company which imports goods from Sub-Co. if Sub-Co. is owned by companies registered outside of Developa. By creating this disincentive, a company from Ecoland would not be able to avoid the surcharge of goods sold in Ecoland by simply registering a company in a different industrialized country and then acquiring Sub-Co. from there. Instead, the chargeable transaction takes place in the UK so that there is no leakage of companies leaving Ecoland or simply registering additional companies abroad to exploit a new loophole, and companies registered in Ecoland would not suffer a competitive disadvantage against companies registered in any other country outside of Developa.

By discouraging the practice through this surcharge, Sub-Co. is then only able to benefit from the concession if it is not a subsidiary of a company based outside of Developa. Of course, companies operating in Developa which do use BAT would not be eligible for any border tax 
adjustment regardless of their ownership. The advantage would be that any company benefiting from the concession would then be a wholly owned entity within Developa, thereby fulfilling the purpose of the concession.

Such a system is not inconceivable, and a similar system exists in the UK pursuant to the rules on "Controlled Foreign Companies" (CFCs). ${ }^{64}$ CFCs are companies ${ }^{65}$ that reside outside the UK but are controlled ${ }^{66}$ by persons (defined to include companies, individuals, and trusts) that reside in the UK, which are taxed at rates below seventy-five percent ${ }^{67}$ of corresponding UK taxes. ${ }^{68}$ When a company that resides in the UK has at least a twenty-five percent interest in the CFC, a charge can be made. ${ }^{69}$ The charge is shared between those UK companies with such an interest in CFCs (the charge is proportionate to the amount of those companies' interest) where they have used foreign territories' low-tax systems to reduce their liability to tax in the $\mathrm{UK} .{ }^{70}$ The charge is equivalent to the corporation tax charge, ${ }^{71}$ less taxes paid in the foreign territory, ${ }^{72}$ meaning that there is no benefit for a UK company manipulating a foreign country's low-tax advantages to avoid corporation tax, since the UK will charge corporation tax in any case. ${ }^{73}$ Dual-resident companies can also be regarded as being resident $^{74}$ in the UK for the amount attributable to UK resident companies. ${ }^{75}$ The overarching purpose of the CFC rules is to prevent multi-national companies from avoiding UK tax by diverting profits to companies registered in countries where profits would be charged to a lower, more

64. Income and Corporation Taxes Act, 1988, § 747(1) (Eng.) [hereinafter ICTA], available at http://www.legislation.gov.uk/ukpga/1988/1/part/XVII/chapter/IV/enacted.

65. Id. $\S 832(1)-(2)$ (defining company as any body, corporated or unincorporated association, but not a partnership), available at http://www.legislation.gov.uk/ukpga/1988/1/section/832/enacted.

66 Id. $\$ 755(2)$, available at http://www.legislation.gov.uk/ukpga/1988/1/part/XVII /chapter/IV/enacted (defining controlling company).

67. Id. $\S 750$ (as amended by Finance Act, 1993, §119(1) \& (2)), available at http://www.legislation.gov.uk/ukpga/1988/1/part/XVII/chapter/IV/enacted.

68. Id.

69. Connected or associated persons holding shares are also counted when calculating the percentage interest. Id. § 747(5) (as amended by Finance Act 1998, § 113 (Eng.)).

70. Id. § 703, available at http://www.legislation.gov.uk/ukpga/1988/1/section/703/enacted.

71. Id. §747(4)(a), available at http://www.legislation.gov.uk/ukpga/1988/1/part /XVII/chapter/IV/enacted.

72. $I d . \S 750(1 \mathrm{~A})$

73. During the drafting of ICTA, the controlled foreign company rules were under review. See Her MAJESTY's TREASURY, supra note 18. Section 36 of the Finance Act of 2009 amended ICTA's controlled foreign company rules. Finance Act, 2009, §36 (Eng.), available at http://www.legislation.gov.uk/ukpga/2009/10/contents.

74. ICTA $\S 747(1)$ (b) (exempting CFCs from the Finance Act of 1994, § 2.249 (Eng.), thus preventing dual-resident companies from claiming single residence under a double tax treaty).

75. See generally John Tiley, Revenue LaW 1173-80 (Hart Publishing, 6th ed. 2008) (providing an overview of CFCs resident in low tax areas). 
preferential rate of corporation tax. ${ }^{76}$ Importantly, this is an anti-avoidance provision, meaning that a tax avoidance motive must be established for any amount to become payable. ${ }^{77}$ It is conceded, however, that such clauses have sometimes proved difficult to enforce.

\section{G. Tax on Dividends}

A problem with the above method is that if a company is performing badly, it may need to defer payments of taxation or may not pay the full amount, so the surcharge would have little actual effect. A solution which is potentially more effective may be to charge shareholders income tax, instead of charging the company corporation tax. This may be a sufficient deterrent to prevent the company from exploitative practices in the first place.

Resident shareholders within Ecoland could be charged a tax on dividends paid out from resident or non-resident companies not using BAT. This would apply the same rules to both parties and, therefore, be nondiscriminatory. The rules could also apply to resident shareholders in resident companies with subsidiary non-resident companies (or as part of a group), so as to include any foreign holdings. Resident shareholders would then lose the incentive to invest in X-Co., and companies would be deterred from not using BAT in either their own company, their subsidiary, or group companies.

The purpose of this proposed tax on shareholder dividends is that the buck stops with the shareholder. Companies in Ecoland may be able to benefit from exploiting developing-country concessions, but their shareholders would inevitably lose out by having their shareholder dividends charged to a higher level of tax than if their company was not involved in this practice. Consequently, the ultimate beneficiaries of the exploitation would be negatively affected, putting pressure on the company to change its practices. Profits gained by the company through exploitation would also be cancelled out if the company's share price fell as a result of the negative implications for shareholders - the company would lose value overall.

To enable a level playing field for Ecoland's resident shareholders and resident companies, against those residing in other industrialized countries,

\footnotetext{
76. International - Controlled Foreign Companies, HeR MAJESTY'S REVENUE \& CUSTOMS, http://www.hmrc.gov.uk/international/technical4.htm (last visited Dec. 7, 2010).

77. ICTA § 747(1). See also INTM208010 - Controlled Foreign Companies: Exemptions - The Motive Test, HER MAJESTY'S REVENUE \& CUSTOMS, http://www.hmrc.gov.uk/manuals/intmanual/INTM208010.htm (last visited Dec. 7, 2010).
} 
shareholders of any company importing goods from Sub-Co. would be charged to the shareholder income tax, if Sub-Co. is owned by a company outside of Developa. Therefore, companies in both Ecoland and other like countries would be affected. Such a tax would prevent companies registering in other industrialized countries from avoiding the shareholder tax and would serve to prevent Ecoland's shareholders from being put at a disadvantage against companies registered in other industrialized countries who sell in Ecoland. The rationale is to create a situation where only companies resident in Developa, with shareholders resident in Developa, could export goods that have not been produced using BAT to Ecoland without being subject to border tax adjustments.

This would have the further advantage of not losing entire holding companies to DCs or other ICs offering a less-strict regime. In the UK, the controlled-foreign-company rules (see Part VII.F.) do not apply when the profits that would be charged are those of an individual (since individuals are not companies), ${ }^{78}$ but individuals that ordinarily reside in the UK are instead similarly charged pursuant to the anti-avoidance provisions relating to the transfer of assets abroad. ${ }^{79}$

A possible risk of discouraging such shareholding, however, is that shareholders in industrialized countries may sell their shares to residents of Developa in order to avoid the surcharge and receive separate payments from the buyers - thereby, ultimately benefiting residents of the industrialized country.

A further loophole remains. If Sub-Co. was wholly owned by shareholders within Developa, it is still possible that it could be a parallel company of a company outside of Developa. This loophole would allow companies in Ecoland or other industrialized countries to import goods from Sub-Co., but still benefit. For example, if shareholders in Sub-Co. were associated with X-Co., such as if they were employees of X-Co. or were otherwise related to employees or shareholders of X-Co., then the risk is that Sub-Co. again would become a tax avoidance mechanism. For example, Sub-Co. could offer goods to X-Co. at prices below the market rate and make no profit itself. General anti-avoidance provisions would be needed to close these loopholes, looking at whether Sub-Co. or its employees or shareholders were associated with counterparts in X-Co. Companies importing goods from Sub-Co., under circumstances where

\footnotetext{
78. ICTA $§ 747(4)(\mathrm{b}), \quad$ available at http://www.legislation.gov.uk/ukpga/1988/1/ section/747/enacted.

79. Id. $\S 739$, available at $\mathrm{http}: / /$ www.legislation.gov.uk/ukpga/1988/1/section/739/enacted.
} 
Sub-Co. is associated with the importing company, would then be liable to the shareholder income tax.

\section{H. Type of Taxation}

For Ecoland's individual shareholders, the charge could then be either the loss of any previously available credit on their current tax liability in respect of the dividend or a surcharge above the higher rate on top of the existing dividend tax. If applied in the UK, this could prove costly to shareholders, which could provide the necessary incentive for their companies. $^{80}$

For Ecoland resident corporate shareholders, the dividend distribution could become liable to corporation tax or charged at a higher rate. ${ }^{81}$ Such an amendment would associate the loss of tax privileges with environmental negativities, removing the incentive to exploit Developa's border-taxadjustment rights, while providing a strong incentive to use BAT elsewhere.

\section{Conditionality}

The attachment of non-trade conditions to trade preferences for developing countries is a legitimate practice under certain circumstances. ${ }^{82}$ For instance, a condition may be that a developing country may not import munitions or may have to improve its human rights record. The prohibition of certain conditions aims to prevent industrialized countries from imposing unreasonable policies within a developing country in exchange for trade preferences. ${ }^{83}$

A condition of granting such preferences could be that any company whose shareholders (or holding company's shareholders) are non-residents must utilize approved PPMs (such as BAT) in order to qualify for the border-tax-adjustment concession. This would have a similar effect as the residency and citizenship requirements discussed at Part VII.E., but would provide the developing country with both the autonomy and responsibility of determining who ought to qualify. This country would be aware that, should this be applied incorrectly, the benefits may be removed altogether. This scheme would also improve the administrative ease because information on shareholders and residents would be more readily available ch. 3 (Eng.)

80. In the UK that charge is outlined by the Income Tax (Trading and Other Income) Act, 2005,

81. In the UK, such a distribution is not currently taxed. ICTA $\S 208$.

82. Appellate Body Report, supra note 41.

83. Switzer, supra note 15 , at 42 . 
to authorities within the developing country. The problem with this proposal, however, is that it burdens the developing country with the cost and administration of dealing with this issue - though the increased level of autonomy and the consequential creation of government employment could make this burden worthwhile.

\section{J. Joint Ventures}

The examples above do not give express consideration to the workability of similar limitation rules where one joint venture company is registered in Developa and its co-joint venture company is registered in Ecoland. Despite the desirability of situations described above, where companies outside of Developa are entirely unable to benefit, it may be the case that companies registered in Developa simply do not have the capacity to operate in such a way where they can make the most of the concessions being offered. Resources, know-how, and capital may be required from outside of Developa in order for its citizens to prosper from exporting goods at all.

Such a situation would seem to call for a dilution of the strict requirements that limit profits to only Developa's residents. However, the policymaker may still decide not to pursue this. Essentially, the primary options available to a policymaker would be as follows.

\section{Allow the Joint Venture to Proceed}

The purpose of this would be to encourage the development of relevant business opportunities in Developa and increase exports. However, the risks highlighted in Part VII.B. would still apply. Specifically, enterprises could exploit the joint venture. The company registered in Ecoland could profit at the expense of Developa's residents.

2. Allow the Joint Venture to Proceed, Limiting the Profits That Can Leave Developa

This allowance would enable the projects in Developa to begin, and help the company registered in Developa to make a profit, alongside other economic benefits in Developa. The policymaker would need to determine the level of profits permitted to leave Developa while profits can still be made. If the level is set too high, then it will be regarded as exploitative and limit the benefits available to Developa residents. If the level is set too low, then there will be too little incentive for outside companies to invest in such joint ventures, and certain projects may not take place. 
3. Allow the Joint Venture to Proceed, on the Condition That the Company Registered in Ecoland Provides the Necessary Long-Term Expenditure to

Replace PPMs with More Environmentally Efficient Methods

The provision of a long-term business plan to replace the PPMs of the company operating in Developa with improved methods could provide a suitable balance. It would recognize the requirements of the policymaker in demanding a higher onus on companies registered outside of Developa, who would subsequently profit from such a system, than companies wholly owned by Developa's residents. It would also enable projects to begin that otherwise may not be able to without the necessary investment or resources. Yet, crucially, it would ensure that the key purpose in allowing such joint ventures would be to provide more environmentally efficient PPMs to developing countries in the long term, and, coupled with the improved economic benefits to Developa, this could prove more beneficial to both environmental and economic objectives than not permitting joint ventures whatsoever.

While some policymakers may demand that the improved technology must be BAT, it may be more appropriate to demand instead that the replaced technology is of a different standard. The rationale for doing this would be that technology that is both cleaner and more appropriate to the labor-intensive requirements of Developa would be adopted, rather than simply technology that is cleaner. In this manner, both the environmental and economic objectives can be reached.

A more restrictive version could also incorporate terms in Part VII.J.3 above.

\section{Prohibit a Company from Avoiding Payment of BAT if It Is in a Joint} Venture with a Company Outside of Developa

This would provide the most administrative efficiency for Ecoland's tax administrators. Further, it would reduce the risk of exploitation and work solely for the purposes behind the Enabling Clause, (i.e., preventing enterprises from profiting from what ought to be a benevolent provision). However, it could be counterproductive if projects in Developa are unable to take place whatsoever.

In summary, the option in Part VII.J.3 would appear the most suitable for both the development needs of Developa and the environmental objectives of Ecoland. It is anticipated that this will form the basis of future research in this area. 


\section{REMISSIONS ABUSE}

This final part examines an additional problem related to the export element of border tax adjustments, rather than the import element of them, and suggests solutions to this problem. When border tax adjustments are used to adjust the cost of an imported good, as if it had been taxed in an importing country, such as Ecoland, it is common for goods produced in Ecoland to also be subjected to a tax adjustment. This can take the form of a tax rebate for the domestic environmental tax charged upon production. ${ }^{84}$ The export tax remission is permissible under WTO law for final goods, or on intermediary goods representing their inputs, given that the remission is not greater than the domestic tax charged, since that would constitute an export subsidy. ${ }^{85}$

The purposes of export remissions are threefold. First, they protect the competitiveness of exports against goods produced in countries without environmental taxation. If this were not the case, then a competitive advantage could be gained by a country without environmental taxation, because their goods may be produced and thus sold at lower cost. The adjustment means that exports are sold in the importing country as if they had been produced in that country.

The second purpose is to allow an importing country to opt to impose its own border tax adjustments, the rationale being that it is the prerogative of the importing state to determine its own environmental policy and reflect this by setting its own border tariffs. A country with domestic environmental taxes would then not be competitively disadvantaged in its exports, in the same way that there is no advantage for a country without domestic environmental taxes when exporting to a country with them; the result is trade neutral. The third purpose is that without such remissions, a product could be subjected to double taxation, upon both export and import - particularly if both countries have environmental taxation - which would prove extremely disadvantageous.

Exports may be available for remissions regardless of how they are produced or it may be dependent upon them having been produced using an approved PPM such as BAT. Despite the competitive importance, a problem

84. See Steve McCorriston \& Ian M. Sheldon, Export Competition and the Remission of Domestic Environmental Taxes, 12 INT'L TAX \& PUB. FIN. 627, 635 (2005) (analyzing the conditions under which a tax rebate for domestic environmental tax on production can work).

85. GATT, supra note 22, Annex I, art. XVI, 61 Stat. A-11, 55 U.N.T.S. 194 (“[E]xemption of an exported product from duties or taxes borne by the like product when destined for domestic consumption, or the remission of such duties or taxes in amounts not in excess of those which have accrued, shall not be deemed to be a subsidy."). 
identified by Johnson is that remitting taxes to all producers regardless of their PPM can neutralize any internal incentive for exporting producers to produce in a more efficient manner ${ }^{86}$ Further, if remissions are available regardless of PPMs, then a risk lies in companies taking advantage of the export remissions.

A company could produce an enormous quantity of products in an unsustainable manner within Ecoland, though not to be sold within Ecoland, since that would attract a non-refundable charge to environmental taxes. Upon export, the relevant environmental taxes charged during production would be refunded. By causing negative environmental externalities within and possibly beyond Ecoland through production, this would fail to serve Ecoland's domestic and possibly international environmental objectives. At the same time, the refunded exports could create demand for low-cost, high-pollution goods within an importing country with no border tax adjustments, even if their own products are subjected to environmental policies. It would become a form of pollution subsidy. This environmental problem could be localized within Ecoland, meaning that Ecoland would suffer the negative externalities while the importing country would be benefiting from low-cost imports.

For example, W-Co. produces in Ecoland but exports its goods. W-Co. is taxed based upon its unsustainable PPMs, as one of its intermediary goods used in the production of its final good is timber sourced from an unsustainable forest within Ecoland. W-Co. sells its final goods to a neighboring country that does not charge any border tax adjustment, though W-Co. itself has a rule requiring that all timber used in its internal production must be sourced from sustainable forests. When W-Co. exports its final product, it is refunded the tax it was charged during production, and makes a profit by being able to undercut similar goods in the importing country. Ecoland, however, is left without a forest. This simplistic explanation exemplifies the potential of unaccounted environmental damage, where the polluter does not pay.

One solution is only to allow refunds on goods produced internally using BAT, in order to promote its use even for exported goods. Yet, if the requirement for exemption of border tax adjustment on imports is the use of BAT, then it is likely that this would reflect internal exemptions; domestically produced goods could already have tax incentives (possibly tax exemptions) for using BAT. Therefore, there would be no refund. The problem of losing competitiveness would remain.

86. Kenneth C. Johnson, Refunded Emission Taxes: A Resolution to the Cap-Versus-Tax Dilemma for Greenhouse Gas Regulation, 35 ENERGY POL'Y 3115, 3117 (2007). 
However, the removal of export refunds would prove disadvantageous because it would put internally-produced exports at a competitive disadvantage against goods produced in pollution havens and remove the extent to which Ecoland could influence a pollution haven to introduce environmental policies in order to put their goods on an equal footing with Ecoland's BAT-produced goods. ${ }^{87}$

Rather than remove the remissions entirely, one option would be to increase the use of "tax occultes" ${ }^{88}$ domestically, which could not be refunded. ${ }^{89}$ However, the counter-effect may be that international competitiveness of national industry is reduced, since costs of production would rise. Imports from countries not using "tax occultes" to the same extent would again become less expensive, since no border tax adjustment would apply to account for this.

A more feasible suggestion is simply to keep the rate of remissions low. ${ }^{90}$ Exporters would not be given full refunds for their taxes through production, but a partial refund would assist them in competing overseas. The competitiveness of exporting sectors not using BAT would only be partially reduced, though reduced to a sufficient extent to encourage the switch to BAT. Exporters not using BAT could not exploit the availability of remissions if it was sufficiently costly to produce goods without BAT, while exporters using BAT could continue to benefit from not being subjected to environmentally damaging production tax in the first place. If this was tied in with incentives to switch to BAT PPMs domestically, such as an exemption on the relevant PPM taxes and capital expenditure allowances, it could create the incentive for producers to switch their PPMs to BAT, rather than continue producing without BAT.

Overall, an innovative low-pollution economy in Ecoland could evolve due to the incentive to change domestic production methods to BAT for both internally-consumed and exported goods.

87. Ismer and Neuhoff consider how border tax adjustments can be utilized as a persuasive tool to encourage non-participants in international environmental treaties to ratify them. Ismer \& Neuhoff, supra note 15 , at 141 .

88. Literally meaning "hidden taxes," "tax occultes" refers to taxes on goods or services which partially input into a product, but could only be included by averaging the extent to which a range of such taxes proportionately contributes to the total taxes on a final product. See James A. McNamara, Tax Adjustments in International Trade: The Border Tax Dispute, 3 J. MAR. L. \& COM. 339, 345 (1972) (discussing "tax occultes" within the India cascade tax systems).

89. Border tax adjustments are not normally applied to "tax occultes" which are defined to include "consumption taxes on capital equipment, auxiliary materials and services used in the transportation and production of other taxable goods." GATT Working Party, supra note 13, ๆ 15(a). Nor are they thought to be made for payroll or social security taxes. Id. $\uparrow 14$. Nor are they ad valorem taxes such as stamp duty, property taxes or registration taxes. $I d$. $\mid 15$ (b).

90. Ismer \& Neuhoff, supra note 15 , at 145. 


\section{CONCLUSION}

A "leakage loophole" exists where industrialized countries offer concessions to imports from developing countries in the form of exemptions from border tariffs, including exemptions from border tax adjustments for goods produced using methods falling short of production methods expected in the importing industrialized countries. Enterprises may deliberately base themselves in such a developing country in order to access the right to export pollution-intensive goods to an industrialized country without paying border tax adjustments, even though the intended beneficiaries of the concession were residents of the producing country. The system of identifying the intended beneficiaries is imperfect, but it remains clear that the benefit should assist the economy of developing countries in need of economic assistance and not enterprises whose profits may not be recycled back into the developing country.

A dividend tax on shareholders can provide the most appropriate incentive for companies based outside of a developing country to avoid breaching any "leakage loophole." Those companies using BAT, who would be able to utilize the Enabling Clause to avoid BAT adjustments at an importing country utilizing such a system, would be restricted to companies regarded as intended beneficiaries. Those companies could not be owned outside of that country, which would severely limit the applicability of the concessions but also provide it to only those for whom it was intended. Foreign investment going into the country would then be for legitimate development purposes and not to exploit their status as a developing country.

It may, however, be necessary to permit a small proportion of shareholders outside of a developing country to partially own a benefiting company-perhaps ten percent-in order to allow enough inward investment to enable companies to start up. However, this could unnecessarily complicate the administrative burden and could send the wrong signal if it is deemed that the environmental objective in question is such that there ought to be no encouragement for an enterprise that could hinder its applicability. In practice, whether there will be some or no foreign ownership will be dependent upon the environmental objective itself on a case-by-case basis, and particularly, whether it is a localized matter or not. If the environmental objective is localized in the country introducing border tax adjustments to prevent it, then this reduces the justification for hindering development in developing countries, but the facts will justify the appropriate action. 
Further exploration is also intended for rules governing joint ventures, where companies from outside the developing country would be able to profit from the concession, given that PPMs are improved in their co-joint venture operating in a developing country in the long term. This could provide the incentive for foreign investment to get projects enabling exports from developing countries to get off the ground, but also ensure that such joint ventures work to transfer knowledge and capabilities from a joint venture company in an industrialized country to its counterpart in a developing country. This can be done by enabling such joint ventures on the basis that more efficient PPMs are implemented in the long term, in order to match the environmental efficiencies offered by BAT. However, rather than requiring BAT, technology could be developed which is both environmentally efficient and capable of providing employment in a developing country with high unemployment. This would provide both employment and meet environmental objectives - though possibly not to the same extent as BAT can. The long-term advances in PPMs could then meet the requirements of similar BAT PPMs, enabling the joint ventures to operate without needing the concessions.

One concern for countries considering introducing internal taxation on shareholders or enterprises is that there may be a migration to other industrialized countries not introducing such rules, which would permit them to continue holding subsidiaries in developing countries, and thus enable them to continue the "leakage loophole." However, since such migration would reduce their access to their original market, whether this risk is appropriate to introduce in a country is dependent upon the strength of their market and how appealing it is for companies to be able to trade there. If a country introduces these rules, they could make it more attractive to operate there by offering tax incentives for companies using BAT. For instance, border-tax-adjustment revenue could be recycled by offering reduced corporation tax for companies using BAT. If, however, the market is not of sufficient attractiveness to retain companies and shareholders, a residents-only provision would likely be the more appropriate solution.

Overall, the fact that such risks can be mitigated should be of comfort to countries wishing to introduce internal environmental taxes, which should therefore help countries achieve domestic and international environmental objectives. 